\title{
Structural mapping of coastal plain sands using engineering geophysical technique: Lagos Nigeria case study
}

\author{
A. A. Adepelumi ${ }^{1}$, M. O. Olorunfemi ${ }^{2}$, D. E. Falebita ${ }^{3}$, O.G. Bayowa ${ }^{4}$ \\ ${ }^{1,2,3}$ Department of Geology, Obafemi Awolowo University, Ile-Ife, Nigeria; ${ }^{4}$ Department of Earth Sciences, Ladoke Akintola Univer- \\ sity, Ogbomoso, Nigeria. ${ }^{1}$ Phone: $+234-8067163658$. \\ Corresponding author: ${ }^{1}$ adepelumi@yahoo.co.uk
}

Received 20 May 2009; revised 1 June 2009; accepted 2 May 2009.

\begin{abstract}
An engineering geological survey using the cone penetrometer and finite element method was carried out to characterize sand-fill thicknesses in a reclaimed area of Lagos, SW Nigeria. A previously developed finite element program was modified in order to allow for predicting the sand-fill thicknesses, and have an understanding of the geomorphic shallow structures existing pre-sand-fill. The program was tested using the obtained cone penetrometer test results from the Lekki-Peninsula area. The finite element predicted thicknesses show good correlation with the penetrometer obtained thicknesses. Six zones with thick sand-fill thicknesses varying from 1.25 to $6.0 \mathrm{~m}$ were identified from the isopach maps, these zones correlate with major/minor depression associated with river/stream channels and creeks. These are the main shallow geomorphic structural features present in the area pre-sand fill. The structural trends of the depressions are largely influenced by the oceanic fracture pattern.
\end{abstract}

Keywords: Sand-Fill; Finite Element; Nigeria; Penetrometer; Depression

\section{INTRODUCTION}

Engineering site investigation requires determination of thicknesses either to competent bedrock in foundation works or of sand-fill columns in a reclaimed site. Accurate mapping of bedrock topography or reliable estimation of sand-fill in a reclaimed site requires that thicknesses are known at several test points. The more the number of test points, the better the bedrock topography definition and the more accurate is the estimation of spatial volume. However, the more the number of test points, the higher is the cost of investigation and the longer is the survey duration, most especially where the survey area runs into tens of square kilometers [1].

Geophysical methods, cone penetrometer tests, and direct borehole drilling are some of the various means of determining thicknesses or depths to a particular bedrock $[2,3,4]$. Of the three methods outlined above, geophysical methods remain the cheapest. But geophysical data interpretation requires some level of control usually in terms of subsurface information (e.g. lithological logs) obtained from drilling. Hence geophysical investigation is often complemented by borehole investigation with a consequently increasing cost. Survey cost and duration can be reduced if a predictive technique, with significant level of accuracy, can be developed that utilises few initial accurately determined thicknesses to predict thicknesses at other location where tests have not been carried out.

Finite element automated approach to the prediction of heads have been utilised by a number of authors. These include Fenner [5], Agbede [6] and Wang and Anderson [7]. These methods are iterative procedures that utilise various elemental geometries such as polygons, rectangles and triangles. The Finite element program, developed by Wang and Anderson [7] was slightly modified and used to predict formation thicknesses. The viability of the technique was tested using cone penetrometer test results from a reclaimed Lekki Peninsula area of Lagos. In the present study, the main objective is to determine the thicknesses of sand-fill using the cone penetrometer tests and finite element methods. And, to have an understanding of the geomorphic shallow structures existing pre sand-fill in the reclaimed Lekki Peninsula area of Lagos Nigeria.

\section{THE STUDY AREA}

The Lekki-Peninsula area of Lagos was reclaimed by hydraulic sand-fill. It is located within the western coastal zone which consists largely of coastal creeks and lagoons developed by barrier beaches associated with sand deposition $[8,9]$. The study area can be found in the south eastern part of Lagos State, southwest, Nigeria, lying between latitude $6^{\circ} 25^{\prime} 44.62^{\prime \prime}$ and $6^{\circ} 27^{\prime} 38.16^{\prime \prime} \mathrm{N}$ 
and longitudes $3^{\circ} 27^{\prime} 16.70^{\prime \prime}$ and $3^{\circ} 28^{\prime} 55.80 \mathrm{E}$ (Fig. 1).

The surface geology of the study area is made up of the Benin Formation (Miocene to Recent), recent littoral alluvial, lagoons and coastal plain sand deposits. The sand range in size from coarse to medium grained clean white loose sandy soil which graded into one another towards the lagoons and near the mouth of the larger rivers. The low-lying beach ridges of sand called berm and barrier beach ridges of sand are ubiquitous in the area and are said to be derived from one or more of the following, sand brought in along the coast and reworked alluvial sands originally deposited by the south flowing rivers drawing the Dahomey basement of the western Nigerian during the late Pleistocene, Wurm-Wisconsn
[10]. The superficial deposit in the pre-sand fill is composed mainly of the clay/peat deposits. The recent littoral and alluvium deposits, the continental Benin sands and the Ilaro Formations were identified as the major aquifers. The water bearing aquifers consist of sands, gravels or a mixture of the two [11]. Within Lagos metropolis, three major aquifer zones at depths shallower than $200 \mathrm{~m}$ were delineated. The first is a water table aquifer that is prone to pollution. The second and third aquifers are confined aquifers made up of an alternating sequence of sand and clay. They are harnessed through boreholes and are the basis of mini-water works in Lagos area. The third aquifer is the most productive and most exploited.

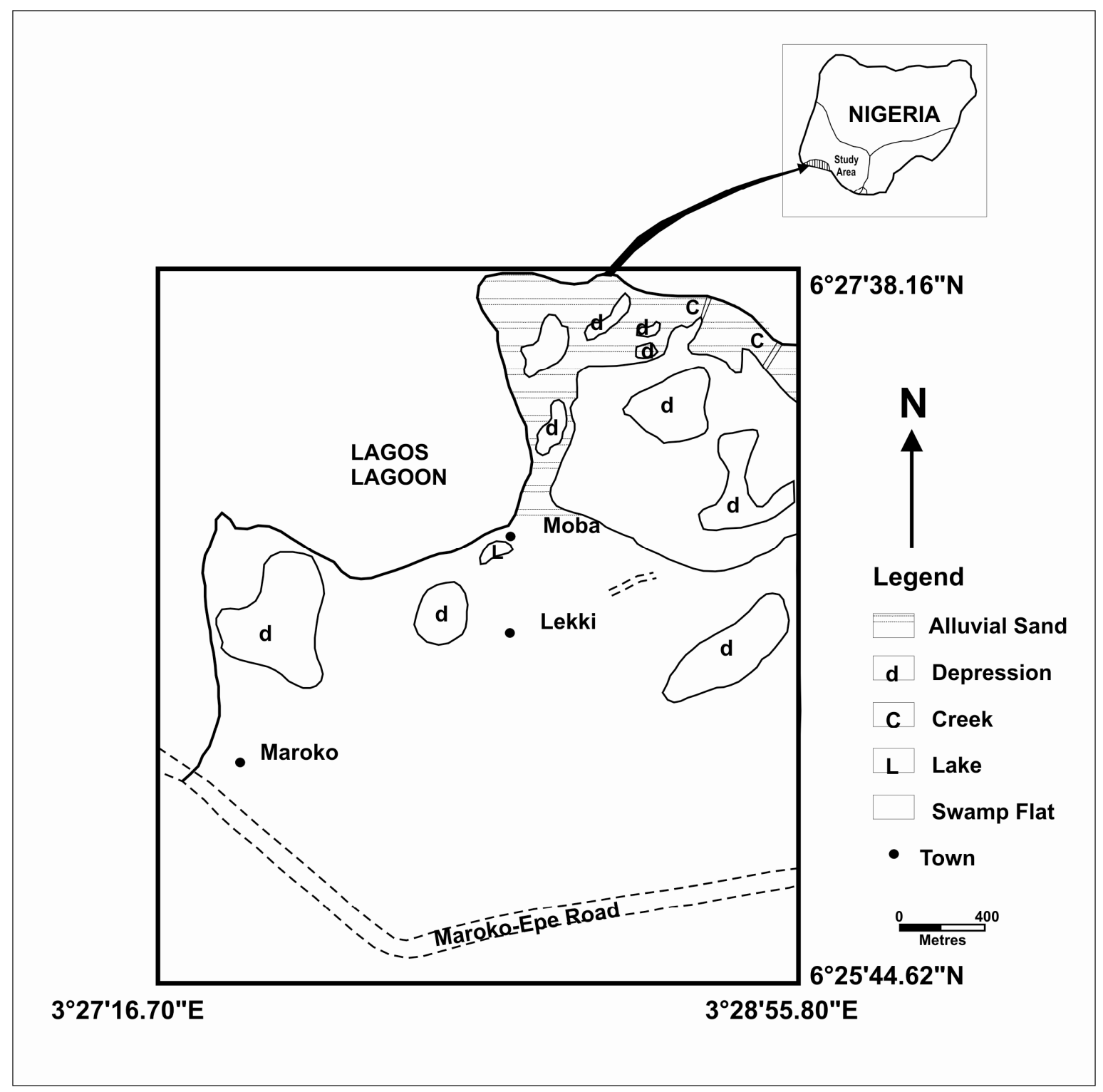

Figure 1. Location map of Lekki-Peninsula, Lagos, Southwestern Nigeria. 
Cone penetrometer tests were first carried out in the study area in order to determine the hydraulic sand-fill thicknesses. For the computation of the unknown thicknesses using the finite element program, the survey area was broken into 191 triangular meshes with 147 test points. The input data are the, number of nodes, the number of elements and the nodal coordinates for each node.

\section{METHODOLOGY}

\subsection{Cone Penetrometer}

Cone penetrometer test is one of the most widely used direct methods in soil testing. The application of the method in geotechnical practice has been reviewed by Sanglerat [12] and de Ruiter [13]. It was designed as a control for the indirect geophysical method [14] and to determine the properties of the insitu soil like its sequence or profile. The penetrometer test was carried at one hundred stations with stations coinciding with the nodes of the finite element triangular meshes.

The force required to drive the probe into the ground (that is, penetration resistance) and the depth of penetration were recorded at each station. The penetration
Test Point 14

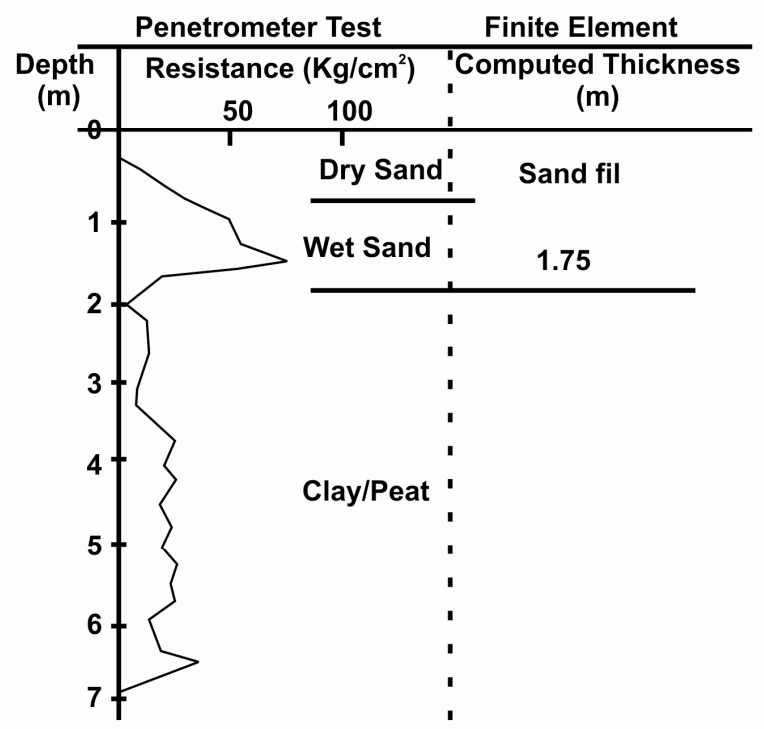

Test Point 33

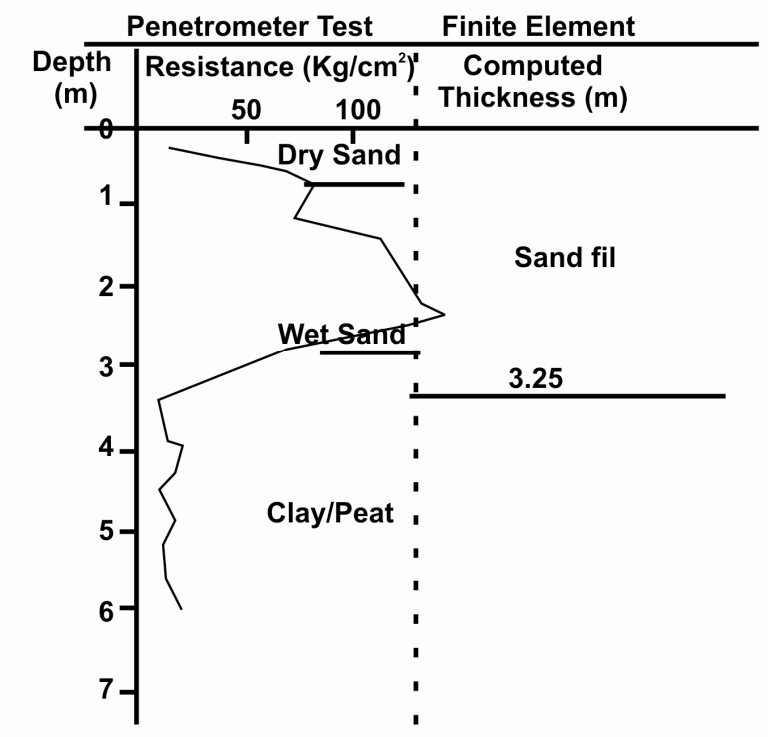

Test Point 21

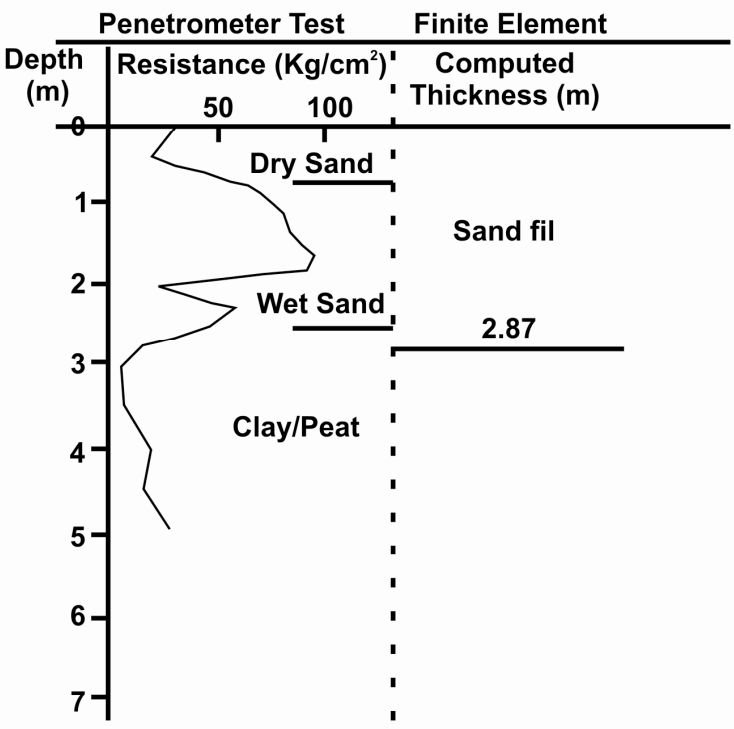

Test Point 52

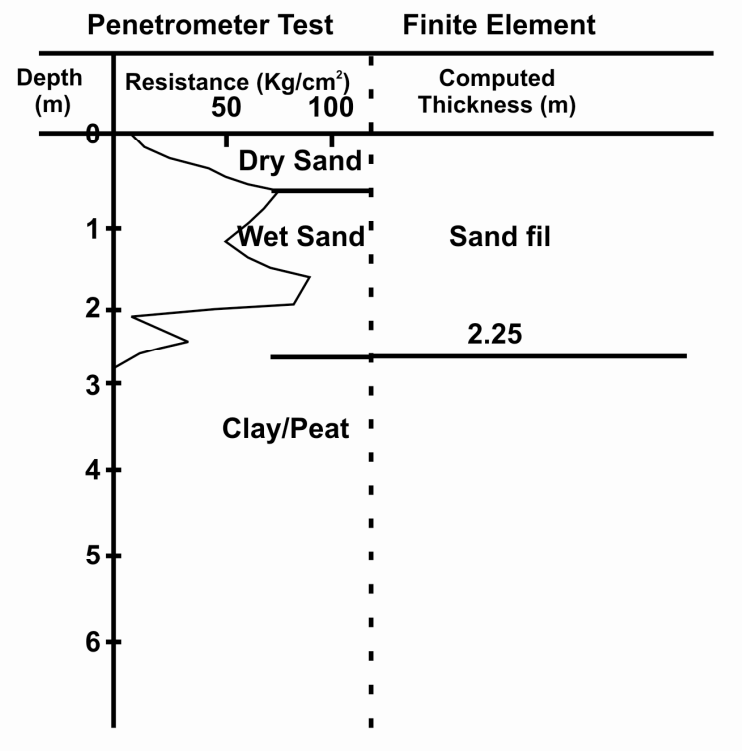




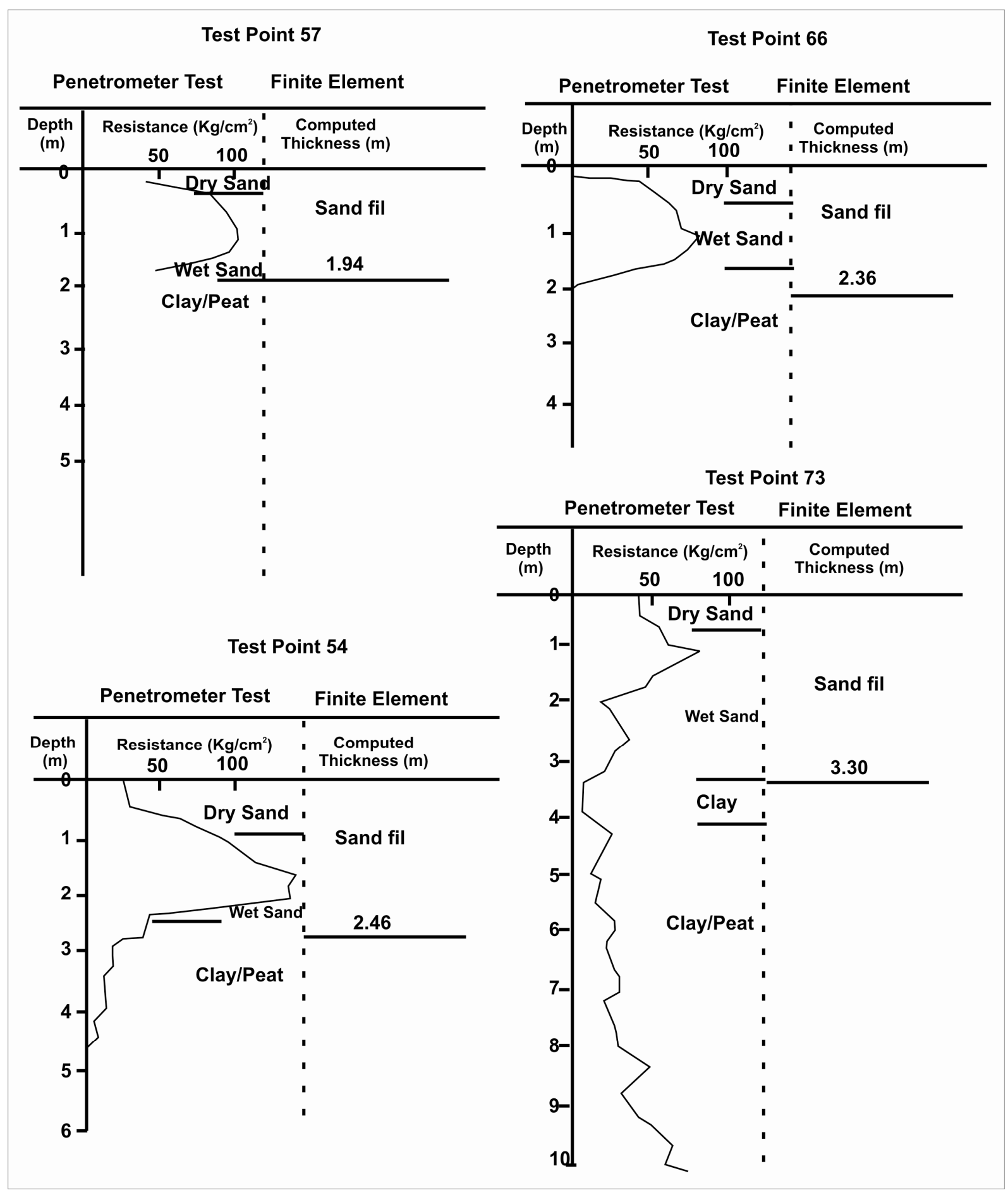

Figures 2a \& b. Comparison of the penetrometer curves with the finite element results.

resistance in $\mathrm{Kg} / \mathrm{cm}^{2}$ was plotted against depth of penetration. In view of the envisaged resistance contrast between the sand-fill and peat/clay or sandy clay bedrock, this method was chosen for the study. The inflection points of the penetrometer curves were interpreted as the interface between the different lithologies.

\subsection{Finite Element Method}

The program presented here is based on the application of variational or weighted residual principle. The problem domain is visualized as a triangular element with four nodes at the corners. The nodes are the points within the problem domain at which thicknesses are computed 
Fenner [5]. The residual at each point in the problem domain is a measure of the degree to which the thickness does not satisfy the governing equation. A trial solution $t(x, y)$ is built up as a continuation of the basis function

Table 1. Comparison of the penetrometer tests ad finite element results.

\begin{tabular}{|c|c|c|c|c|c|c|c|c|}
\hline $\begin{array}{c}\text { NODE } \\
\text { NUMBER }\end{array}$ & $\begin{array}{c}\text { PENETROME } \\
\text { TER } \\
\text { THICKNESS } \\
\text { (m) }\end{array}$ & $\begin{array}{c}\text { FINITE } \\
\text { ELEMENT } \\
\text { THICKNESS } \\
(\mathrm{m})\end{array}$ & $\begin{array}{c}\text { NODE } \\
\text { NUMBER }\end{array}$ & $\begin{array}{c}\text { PENETROME } \\
\text { TER } \\
\text { THICKNESS } \\
\text { (m) }\end{array}$ & $\begin{array}{c}\text { FINITE } \\
\text { ELEMENT } \\
\text { THICKNESS } \\
(\mathrm{m})\end{array}$ & \begin{tabular}{|c|} 
NODE \\
NUMBER
\end{tabular} & $\begin{array}{l}\text { PENETROME } \\
\text { TER THICK- } \\
\text { NESS } \\
(\mathrm{m})\end{array}$ & $\begin{array}{c}\text { FINITE } \\
\text { ELEMENT } \\
\text { THICKNESS } \\
(\mathrm{m})\end{array}$ \\
\hline 1 & 1.25 & - & 51 & 2.75 & - & 101 & 2 & 2.07 \\
\hline 2 & - & 1.5 & 52 & 2.25 & 2.25 & 102 & 2.5 & 2.32 \\
\hline 3 & 1.5 & - & 53 & 2.25 & - & 103 & 2 & \\
\hline 4 & 1.75 & - & 54 & 2.25 & 2.46 & 104 & 2 & 1.8 \\
\hline 5 & 1.75 & - & 55 & 2.25 & - & 105 & - & 1.51 \\
\hline 6 & 1.5 & - & 56 & 6.75 & - & 106 & & 1.4 \\
\hline 7 & - & 1.75 & 57 & 1.94 & 1.94 & 107 & & 1.37 \\
\hline 8 & 1.5 & - & 58 & 1 & - & 108 & 2.25 & 2.1 \\
\hline 9 & - & - & 59 & 2.5 & - & 109 & 2.5 & 2.06 \\
\hline 10 & - & - & 60 & - & 1.5 & 110 & 2 & 1.76 \\
\hline 11 & 2 & - & 61 & - & 1.4 & 111 & - & 1.49 \\
\hline 12 & 1.75 & - & 62 & - & 4.36 & 112 & 2 & - \\
\hline 13 & 1.6 & - & 63 & 2 & - & 113 & - & 1.37 \\
\hline 14 & 1.75 & 1.75 & 64 & 5.6 & - & 114 & - & 1.33 \\
\hline 15 & 3.25 & 3.25 & 65 & 2 & 3.43 & 115 & 2.25 & 2.16 \\
\hline 16 & 2 & 2 & 66 & 1.7 & 2.36 & 116 & 2.25 & 2.14 \\
\hline 17 & 1.7 & - & 67 & 2.14 & - & 117 & 3 & 1.74 \\
\hline 18 & 3.4 & - & 68 & 1.5 & 1.63 & 118 & 2.5 & 1.47 \\
\hline 19 & - & 3.9 & 69 & - & 1.56 & 119 & - & 1.34 \\
\hline 20 & - & 3.39 & 70 & 3 & - & 120 & - & 1.3 \\
\hline 21 & 2.5 & 2.87 & 71 & - & 2.71 & 121 & 2 & 2.24 \\
\hline 22 & 2 & 2.88 & 72 & 2 & 2.82 & 122 & 2.75 & - \\
\hline 23 & 2.5 & 3.2 & 73 & 3.2 & 3.3 & 123 & 2.75 & 1.81 \\
\hline 24 & 2.25 & 2.86 & 74 & 1.2 & 2.26 & 124 & - & 1.47 \\
\hline 25 & - & 4.42 & 75 & 2 & 1.89 & 125 & 2.2 & - \\
\hline 26 & - & 4.36 & 76 & 1.5 & - & 126 & - & 1.31 \\
\hline 27 & 2.5 & 3.17 & 77 & 2 & - & 127 & - & 1.25 \\
\hline 28 & 2.2 & - & 78 & 2.2 & 2.61 & 128 & 3.5 & 2.01 \\
\hline 29 & 2.5 & 3.78 & 79 & 2 & 2.44 & 129 & 3.5 & 1.79 \\
\hline 30 & 2 & 3.03 & 80 & 1.75 & 2.26 & 130 & 2.5 & 1.46 \\
\hline 31 & - & 4.49 & 81 & 1.5 & 1.86 & 131 & - & 1.46 \\
\hline 32 & 6 & - & 82 & - & 1.63 & 132 & - & 1.27 \\
\hline 33 & 3.25 & 3.54 & 83 & 2.2 & - & 133 & - & 1.19 \\
\hline 34 & 3.5 & 3.77 & 84 & - & 1.49 & 134 & 3 & 1.88 \\
\hline 35 & 3.75 & 4.59 & 85 & 2 & 1.45 & 135 & 2.25 & - \\
\hline 36 & 2.2 & 3.05 & 86 & 2.2 & - & 136 & 2.5 & 1.98 \\
\hline 37 & 2 & - & 87 & 3.25 & 2.33 & 137 & 1.25 & - \\
\hline 38 & - & 2.91 & 88 & 1.75 & - & 138 & - & 1.48 \\
\hline 39 & 3 & - & 89 & 1.5 & 1.72 & 139 & - & 1.23 \\
\hline 40 & 3.5 & 3.77 & 90 & - & 1.55 & 140 & - & 1.12 \\
\hline 41 & 3 & - & 91 & - & 1.45 & 141 & 1.6 & - \\
\hline 42 & 2 & 2.8 & 92 & - & 1.42 & 142 & 1.5 & - \\
\hline 43 & 2 & 3.04 & 93 & 1.5 & 2.29 & 143 & 2.5 & - \\
\hline 44 & - & 2 & 94 & 2.25 & - & 144 & 2.5 & - \\
\hline 45 & - & 2 & 95 & 2 & 2.17 & 145 & 1.5 & - \\
\hline 46 & 2 & 2.5 & 96 & 2.25 & 1.75 & 146 & 1.2 & - \\
\hline 47 & - & 2 & 97 & - & 1.53 & 147 & 1 & - \\
\hline 48 & 1.75 & - & 98 & 2.25 & - & & & \\
\hline 49 & 3.2 & - & 99 & - & 1.43 & & & \\
\hline 50 & 2 & - & 100 & - & 1.39 & & & \\
\hline
\end{tabular}


expressed as a series summation.

$$
t(x, y)=\sum_{L=1}^{N N O D E} t L N_{L}(x, y)
$$

$\mathrm{L}=$ The nodal number

$t=$ An approximate or trial solution

For the computation of the unknown thicknesses by the program, the triangular mesh was digitized at equal intervals of $500 \mathrm{~m}$. The accuracy of the predicted thicknesses is strongly dependent on the accuracy of the initial guess or starting thicknesses and the size of the nodal spacing. The thicknesses were predicted for stations (nodes) at which penetrometer tests have been carried out and at which no penetrometer tests were carried so as to cover the entire survey site.

\section{RESULTS AND DISCUSSION}

The typical cone penetration curves obtained in the study area are shown in Fig. 2. As can be seen from the figures, the curves generally show relatively low resistance (0-60 $\mathrm{Kg} / \mathrm{cm}^{2}$ ) within the uppermost layer of loose/ uncompacted dry sand. This increases to some $60-150 \mathrm{Kg} / \mathrm{cm}^{2}$ in the wet compacted sand, dropping sharply to between 5 and $45 \mathrm{Kg} / \mathrm{cm}^{2}$ in the underlying clay peat and sandy clay horizons. The penetrometer tests delineated three to four lithologic units. The topsoil of dry and loose sand, wet sand, sand clay/clay or peat bedrock. It was observed in general that, the first two layers constitute the sand-fill (Fig. 2) whose thicknesses vary from 1.25 to $6.00 \mathrm{~m}$ (Table 1).

The finite element predicted thicknesses are presented in Table 1. The results were compared with the penetrometer obtained sand-fill thicknesses. It is observed that the finite element derived thicknesses are in good agreement with the penetrometer test thicknesses with a few exceptions at stations 29,30,35, 65, 74 and 93, where very high percentage deviation of between 51 to $88 \%$ were obtained; these fairly large deviation may be due to insufficient input data to act as control around these stations.

The good correlation between the finite element predicted thicknesses and that obtained from the penetrometer test results imply that, given a limited accurate thicknesses as input data, the finite element program would predict the thicknesses at unknown stations to within a reasonable level of accuracy. The close agreement also indicates that the finite element predicted thicknesses could be reliably used for formation thickness estimation in the absence of sufficient penetrometer test results.

Fig. 3 is an isopach map prepared from finite element predicted thicknesses. The map shows sand thick-

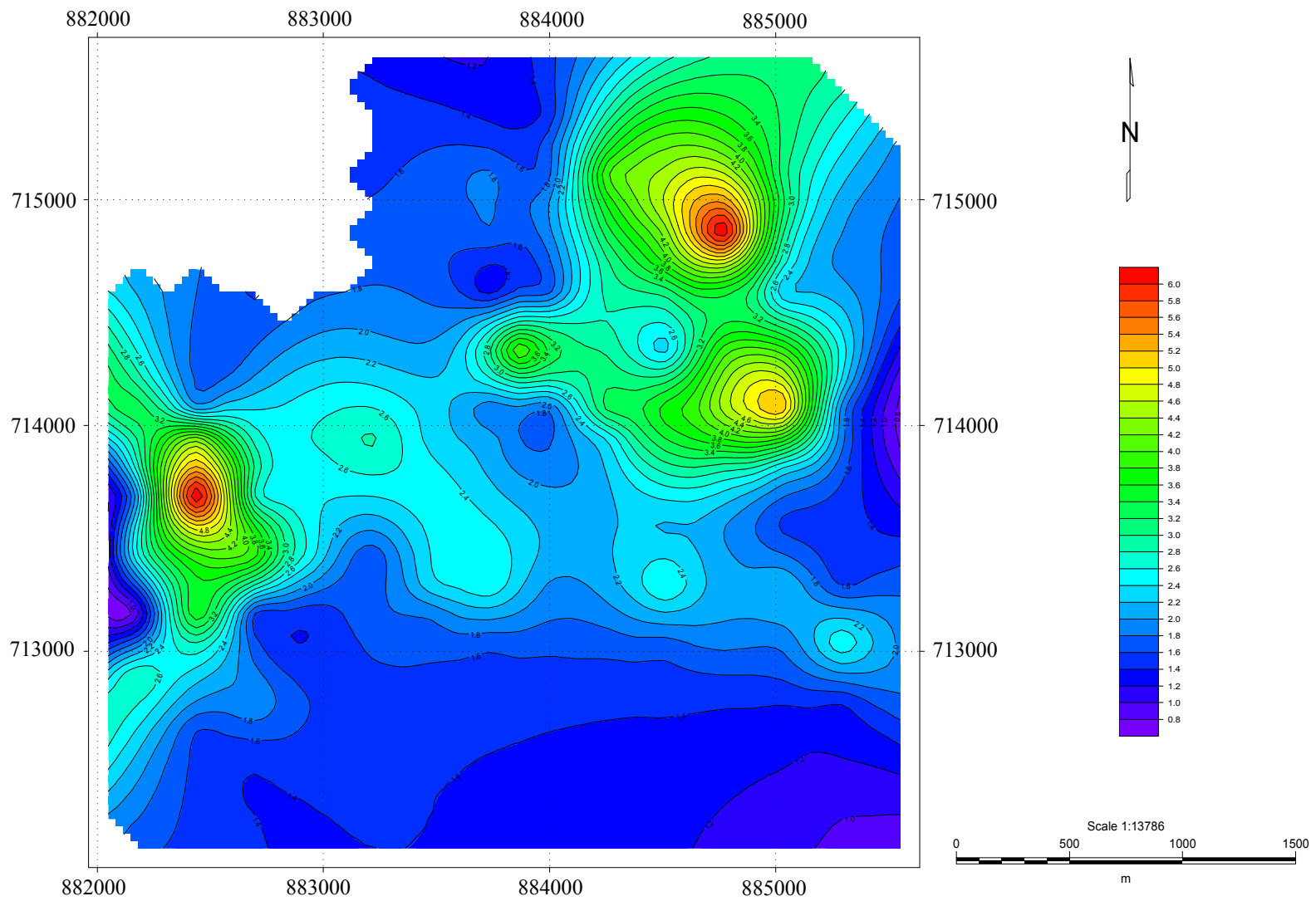

Figure 3. Isopach map of the sand-fill using the computed finite element result. 


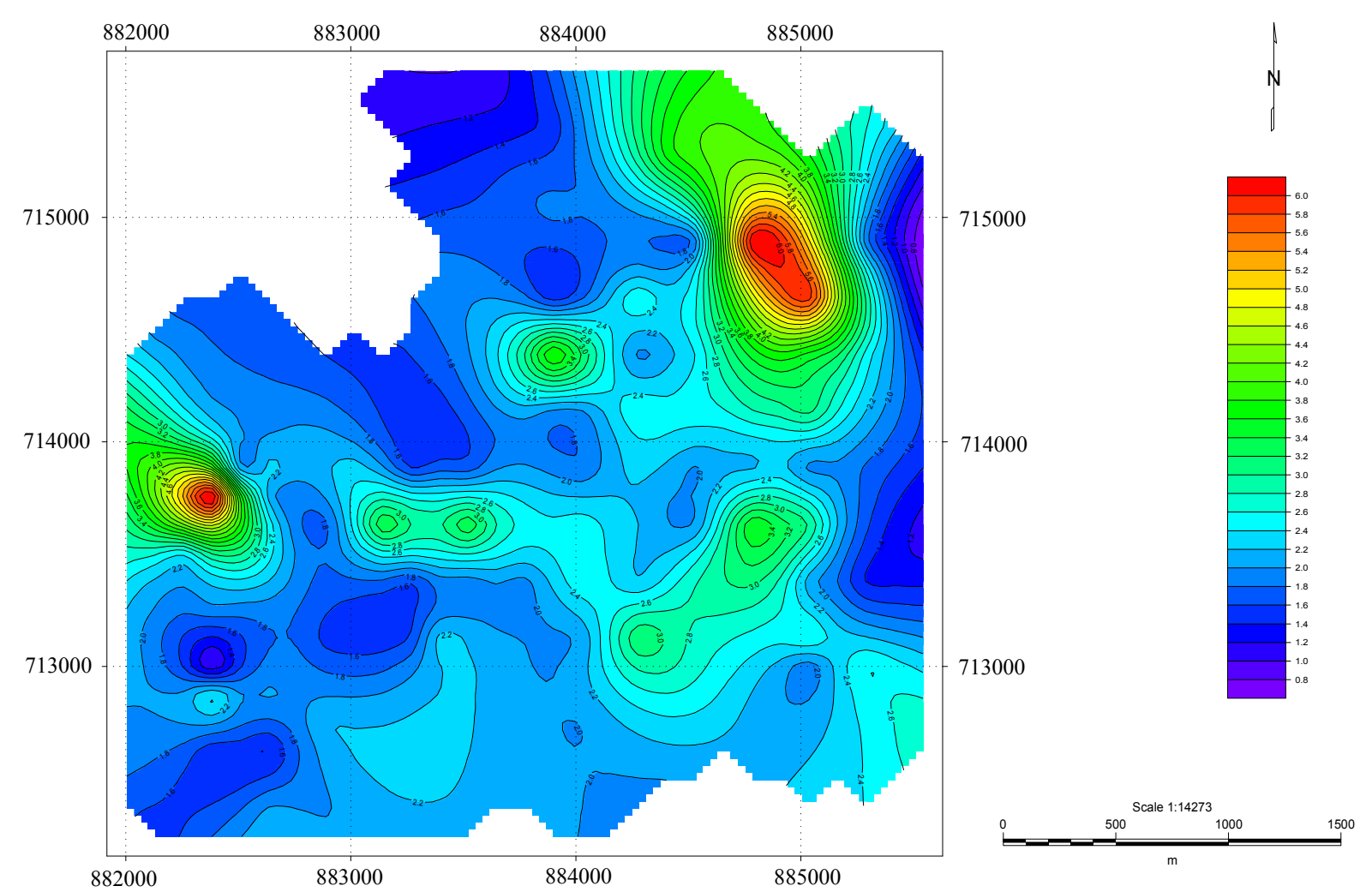

Figure 4. Isopach map of the sand-fill using the penetrometer obtained thicknesses.

nesses varying from 1.25 to $6.0 \mathrm{~m}$ in the area labeled $\mathrm{t} 1$, $\mathrm{t} 2, \mathrm{t} 3, \mathrm{t} 4, \mathrm{t} 5$ and $\mathrm{t} 6$. This zone corresponds to basement depression associated with river/stream channels and creeks in the area which are the main shallow structural features in the surveyed are pre-sand fill. The structural trend of the depressions is largely influenced by the oceanic fracture pattern (NW-SE, NNE-SSW, N-S, and E-W) earlier delineated by Emery et al. [15]. This map compares well with the isopach map prepared from penetrometer obtained thicknesses (Fig. 4) with thick sand zone correlating.

\section{CONCLUSIONS}

The qualitative and quantitative interpretation of the penetrometer test results provided adequate information regarding the structural disposition of the geomorphic shallow structures existing pre-sand-fill. From the penetrometer test, the first two layers constitute the sand-fill with thicknesses varying from 1.25 to $6.00 \mathrm{~m}$. Good correlations exist between the finite element, and the penetrometer thicknesses with few exceptions. The isopach maps show area of basement depression corresponding to ancient river/stream channels and creeks with structural disposition trending in the NE-SW, NW-SE, NNE-SSW, N-S and E-W. The result shows that, finite element method is an efficient means of predicting formation thicknesses that can help considerably in re- ducing engineering geophysics survey costs.

\section{REFERENCES}

[1] Adepelumi, A. A. and Olorunfemi, M. O. (2000) Engineering geological and geophysical investigation investigation of the reclaimed Lekki Peninsula, Lagos, Southwest Nigeria. Bulletin of Engineering, Geology and the Environment, 58, 125-132.

[2] Kearey, P. and Brooks, M. (1984) An introduction to geophysical exploration. Blackwell Scientific Publication, Oxford, 198-217.

[3] Olorunfemi, M. O. and Mesida, A. (1987) Engineering geophysics and its application in engineering site investigations (Case study from Ile-Ife area). The Nigerian Engineering, 22(2), 57-66.

[4] Olorunfemi, M. O. and Okhue, E. T. (1992) Hydrogeologic and geologic significance of a geoelectric survey at Ile-Ife, Nigeria. Journal of Mining and Geology, 28(2), 221-229.

[5] Fenner, R. (1975) Finite element method for engineers. Macmillan Press Ltd. London, 171-171.

[6] Agbede, A. A. (1981) The finite element analysis of the opa river dam. Unpublished M. Sc. Thesis, Obafemi Awolowo University, Ile-Ife, 32-32.

[7] Wang, H. F. and Anderson, M. P. (1982) Groundwater modelling with finite difference and finite element methods. Elsevier Publishing, Amsterdam, 1-137. 
[8] Buchanan K. M. and Pugh J. C. (1955) Land and people in Nigeria: The human geography of Nigeria and its environmental background. London, University of London Press.

[9] Webb J. E. and Hill M. B. (1958) Ecology of Lagos lagoons (II): The topography and physical features of Lagos harbor \& Lagos lagoons. Philosophical Transaction of Royal Society, London, B24, 319-333.

[10] Durotoye, A. B. (1975) Quaternary sediments in Nigeria. Geology of Nigeria, Elizabeth Press, Lagos, 431-451.

[11] Bureau de Recherches Geologiques et Minieres (1979) Pre-drilling hydrogeological report area 18 and 19 submitted to the Federal Department of Water Resources, Lagos, Nigera, 1-60.
[12] Sanglerat, G. (1972) The penetration and soil exploration. Development in geotechnical engineering, Elsevier Scientific Publishing, New York, 52-80.

[13] De Rutter, J. (1981) Current penetrometer practice. American Society of Civil Engineers Convention, St. Louis, State of the Art report, Session 35, 64-64.

[14] Scott, C. R. (1969) An introduction to soil mechanics and foundations. Applied Science Publishers Ltd, London, 379-399.

[15] Emery, K. O. E., Uchupi, J. P., Bowin, C. and Mascle, J. (1975) Continental margin off western Africa-Angola to Sierra Leone. American Association of Petroleum Geologist Bulletin, 59, 2209-2265. 